\title{
Correction to: C3 levels and acute outcomes in Shiga toxin-related hemolytic uremic syndrome
}

\author{
Alejandro Balestracci $^{1}$ (D) $\cdot$ Luciana Meni Battaglia $^{1} \cdot$ Ismael Toledo $^{1} \cdot$ Laura Beaudoin $^{1} \cdot$ Caupolican Alvarado $^{1}$
}

Published online: 30 October 2019

(C) IPNA 2019

\section{Correction to: Pediatric Nephrology}

https://doi.org/10.1007/s00467-019-04334-3

Due to an unfortunate error during the processing of the article, the spelling of the second author name was incorrect. The name should read Luciana Meni Battaglia.

Publisher's note Springer Nature remains neutral with regard to jurisdictional claims in published maps and institutional affiliations.

The online version of the original article can be found at https://doi.org/ 10.1007/s00467-019-04334-3

Alejandro Balestracci abalestracci@yahoo.com.ar

1 Nephrology Unit, Hospital General de Niños Pedro de Elizalde, Montes de Oca 40, CP - 1270 Autonomous City of Buenos Aires, Argentina 